\title{
Encouraging Innovation that Protects Environmental Systems: Five Policy Proposals
}

\author{
Cameron Hepburn*, Jacquelyn Pless ${ }^{* *}$, and David Popp ${ }^{* * *}$
}

27 October 2017

\begin{abstract}
Human innovations have created widespread human prosperity. However, they are also threatening the global environmental systems on which our economy and civilisation depend. The likely solutions to these challenges-such as the transition to clean energy systems-will require yet more innovation. This article presents five policy proposals that would support more innovation of the environmentally beneficial kind and less innovation of the environmentally harmful kind. We argue that the appropriate portfolio of innovation policies for protecting global environmental systems includes: 1) pricing natural capital; 2) providing and targeting R\&D support towards environmentally-beneficial innovations, based on the evidence acquired through more rigorous experimental designs; 3) providing earlystage deployment subsidies for environmentally-friendly technologies in carefully-defined circumstances; 4) supporting collaborative $\mathrm{R} \& \mathrm{D}$ to leverage complementary capabilities in different sorts of organisations; and 5) reducing barriers to private-sector environmental finance. Policies in these five areas could help redirect innovation towards environmentallyfriendly economic activities.
\end{abstract}

JEL-Classification: Q01, Q55, Q58

Keywords: Innovation, life support systems, planetary boundaries, Research and Development (R\&D), environmental economics, technological progress

* Smith School of Enterprise and the Environment and the Institute for New Economic Thinking at the Oxford Martin School, University of Oxford, UK; London School of Economics and Political Science, Grantham Research Institute UK; e-mail: cameron.hepburn@new.ox.ac.uk

${ }^{* *}$ Institute for New Economic Thinking at the Oxford Martin School, University of Oxford, UK; e-mail: jacquelyn.pless@inet.ox.ac.uk

*** Center for Policy Research, The Maxwell School, Syracuse University, USA; National Bureau of Economic Research, USA; e-mail: dcpopp@maxwell.syr.edu

We are grateful to Alexander Teytelboym for their comments on this paper, and we express our gratitude to Frank Convery for encouraging us to pursue this paper and to Suzanne Leonard for her patience. Hepburn and Pless gratefully acknowledge financial support from Partners for a New Economy (P4NE) and the Oxford Martin School. 


\section{INTRODUCTION}

Innovation drives economic growth (Aghion and Howitt, 1998) and enhances standards of living. However, the resulting economic growth also undermines the global environmental systems on which our economy and very civilisation depend. While the concerns of Malthus (1798) have thus far been misplaced - the number of humans on Earth and consumption per capita have simultaneously expanded since the industrial revolution - there is nevertheless undeniable pressure on air, water, food, and energy systems (Rockström et al, 2009; Steffen et al, 2015). These pressures, in turn, are affecting public health and human development (WHO, 2014), threatening some of the gains in prosperity achieved as a result of innovation and jeopardizing the prosperity of future generations.

Yet innovation also must be harnessed to help solve our global environmental challenges. The direction of innovation (Acemoglu et al., 2012; Aghion et al., 2016; Acemoglu et al., 2016) is therefore perhaps more important than the pace of innovation. Without cheaper forms of zero-carbon energy, transport, and agriculture, it likely will be impossible to meet the climate targets of the 2015 Paris Climate Agreement; more innovation in high-carbon technologies may make matters worse. Moreover, the 16 other "global goals" - i.e., the unanimously agreed-upon Sustainable Development Goals (SDGs) that apply to all countries, rich and poor - present humanity with a set of challenges and tradeoffs that appear nearly impossible to meet without fundamental innovations to bring the costs of clean technologies below the costs of environmentally damaging technologies. ${ }^{1}$

It is therefore critical to be able to distinguish between innovations that enhance global environmental systems and those that undermine them. This is not easy. ${ }^{2}$ The consequences

\footnotetext{
1 The SDGs aim to end poverty, protect the planet, and ensure prosperity for all and were adopted by world leaders at a UN Summit in 2015, officially coming into force on January 1, 2016 (UN 2017).

${ }^{2}$ Consider the 2017 U.S. Department of Energy budget, for instance, which includes $\$ 617.5$ million for fossil fuel R\&D and \$822.5 million for renewable energy R\&D (Gallagher and Anadon, 2017). Interpreting whether these figures reflect public support allocations for clean or dirty R\&D is not
} 
of new innovations are often complex and cut across multiple environmental and economic systems. For instance, the increasing push for electric vehicles as a way to reduce air pollution and greenhouse gas emissions potentially creates water problems and the prospect of disposing of more than 10 million tonnes of spent lithium-ion batteries that release toxic gases (Nedjalkov et. al., 2016) if not carefully recycled.

The basic economic case for public support of innovation is simple. Without government intervention, markets under-supply innovative activity because firms do not capture all of the benefits. There are large spillovers associated with knowledge creation (Nelson, 1959; Arrow, 1962)-that is, there are positive externalities associated with knowledge creation since others that do not create the knowledge (or are not responsible for the innovation) can sometimes acquire that knowledge for free-with the social marginal returns from research and development (R\&D) typically estimated to be between 30 and 50 percent, usually more than double the private marginal rates of return (Hall et al., 2010). Moreover, innovations that are environmentally beneficial need not generate lower economic benefits than innovations that are environmentally harmful. Knowledge spillovers actually appear particularly high for environmental technologies, primarily because such innovations are newer: clean electricity technologies induce approximately 20\% more knowledge spillovers than average innovations and $43 \%$ more than dirty electricity innovations (Dechezleprêtre et al., 2015).

Thus, government policies have a vital role to play in shaping the direction, quality, and pace of innovations that affect the environment. Policy instruments can be aimed directly at inducing and accelerating the development and diffusion of new clean products, processes, or services. Such policies might encourage resource efficiency and environmental management, or incentivize R\&D (Dechezleprêtre et al., 2016a) in key sectors, including

trivial. For example, while there are environmental concerns related to the the negative impacts of hydraulic fracturing for natural gas, innovations in fracking methods also helped natural gas surpass coal as the main fuel for U.S. electricity generation. 
agriculture, energy, transport and water. But the relevant policy set is much broader: correcting environmental externalities has been shown to create significant incentives for innovation, even though prices on pollution are not thought of as innovation policies per se (Dechezleprêtre and Popp, 2017). In short, correcting market failures can impact the supply of, and demand for, innovation.

This article proposes and examines five key policies that governments can implement to support innovation that protects the natural environment. We focus on policy instruments that either aim to directly drive innovation (e.g., the provision of fiscal incentives and direct funds for innovative activities) or that indirectly induce innovation (e.g., regulations that make it costlier to operate in dirty sectors, thus inducing innovation in cleaner alternatives) of the environmentally-friendly kind. Our aim here is not to identify a panacea for innovation policy, but rather to provide broad guidance to policymakers and, whenever possible, to make specific recommendations for policy design based upon the theoretical and empirical literature.

\section{POLICY \# 1: PUT A PRICE ON NATURAL CAPITAL}

The most important policy for stimulating innovation that protects the environment is to put a price on unpriced, and increasingly scarce, natural capital. Natural capital-i.e., natural resources through which humans derive services and which sustain human life, such as water and geological formations-comprises approximately $2 \%$ of the wealth in OECD countries and $20 \%$ or more of the wealth in developing economies (World Bank, 2017).

\section{Exhaustible Natural Capital}

Much of the earth's natural capital is exhaustible, comprising oil, gas, subsoil minerals, and other assets. Markets for these minerals and fuels are fairly liquid and well-developed with transparent prices. Concerns about the depletion of such natural capital - including "peak oil" worries - have come and gone in recent decades (e.g., see Helm (2011) for a critique of the peak oil hypothesis and related policy), but the evidence suggests that the trend in 
reserve to production ratios is zero (Hepburn et al., 2017). The risk of exhausting these types of natural capital assets are very low, because scarcity creates high prices, which leads to innovation, further exploration, reuse, and the development of substitutes. Indeed, many economists have long argued that the world is unlikely to "run out" of exhaustible resources due to market incentives and technological innovation (Tilton, 1996). Claims regarding the depletion of exhaustible resources often do not appropriately consider the impact of higher prices that result from exhausting easier-to-access and cheaper deposits, and technological innovation, which is induced by higher prices and turns resources into reserves.

\section{Renewable Natural Capital}

In contrast, the natural capital that is most "at risk" of exhaustion - i.e., where planetary boundaries could be or may already have been crossed - is renewable natural capital. This capital tends to be scarce because it is often incorrectly priced, or has no price at all. Examples include many key systems that support life on earth - biodiversity, the ozone layer, land and water ecosystems. While the climate system is a slowly renewing system too, the capacity of Earth's carbon cycle to adjust for rapidly increasing atmospheric carbon dioxide concentrations without causing irreversible climate change suggests that the atmospheric space for carbon dioxide is better conceived of as an exhaustible resource (Allen et al., 2009). The inadequate prices on these resources is a market failure that reduces the demand for innovation.

\section{Tools for Correcting the Natural Capital Pricing Market Failure}

How can this market failure be corrected? There is a well-known literature in environmental economics on the policy tools available (e.g., Goulder and Parry, 2008). These tools include direct pricing (e.g., through taxation), trading, or command-and-control instruments that ban or limit certain activities or set technical standards. Implementing more stringent environmental regulations and policies makes it costlier to pollute, and thus changes the relative costs and benefits of competing technologies. For example, a tax on carbon makes 
electricity generation from dirty fossil fuels such as coal more expensive than electricity generated from solar energy systems (Greenstone and Looney, 2012). As the cost of carbonemitting technologies and activities increases, there is a financial incentive to move away from dirty technologies and activities. This encourages a market in clean technologies to form, which encourages more innovation in environmentally-friendly technologies and thus stimulates clean R\&D (Baranzini et al., 2017). This hypothesis -- known as the "induced innovation hypothesis" - suggests that policies that put appropriate prices on natural capital should be a major component of any policy portfolio aimed at redirecting technological change towards innovation for protecting the environment (Acemoglu et al., 2012; Aghion et al., 2016; Acemoglu et al., 2016; Fischer et al., 2017).

\section{Evidence on the Induced Innovation Hypothesis}

The induced innovation hypothesis-that more stringent environmental regulations and prices lead to greater R\&D activity and innovation in environmentally-friendly sectors-is widely supported by the theoretical and empirical literature (Hicks, 1932; Acemoglu, 2002; Acemoglu et al, 2016; Lanjouw and Mody, 1996; Jaffe and Palmer, 1997; Newell et al., 1999; Popp, 2002; Brunnermeier and Cohen, 2003; Popp et al., 2010; Johnstone et al., 2010; Ambec et al., 2013; Calel and Dechezleprêtre, 2016). The empirical evidence indicates that the response to environmental regulation or prices is both large in magnitude and fast, typically occurring within five years. ${ }^{3}$

However, the literature indicates that the impact on innovation may vary depending on instrument choice. Market-based and flexible instruments such as emissions taxes or tradable allowances provide flexibility to firms to choose technical solutions that reduce compliance costs and can even enhance innovation and foster organizational change (Burtraw, 2000). Putting a price on activities, such as carbon dioxide emissions, that damage

\footnotetext{
3 The response is even faster for regulation. For example, Popp (2006) finds that clean air regulations
} in the U.S., Japan, and Germany have led to almost immediate innovation responses. 
natural capital, can create stronger economic incentives for improving abatement technologies relative to setting standards (Jaffe and Stavins, 1995). Importantly, however, market-based policies like carbon pricing must be credible to private sector firms over the long term to ensure sufficient demand for innovations once they are ready for the market (Helm et al., 2003; Newell, 2010). There is evidence that performance standards can lead to more innovation than prescriptive standards (Lanoie et al., 2011). However, although market-based mechanisms-such as subsidies and taxes-are often found to be more effective in encouraging innovation than command-and-control regulations (Jaffe et al., 2004), no clear evidence has emerged concerning which demand-side subsidies and policies have the greatest impact on innovation (Requate, 2005). While the details remain to be worked through, the literature powerfully tells us that environmentally-friendly innovation can be stimulated by policies that address environmental externalities.

Policies that direct research efforts towards cleaner technology have the added benefit of directing innovation efforts away from dirtier technologies. Within the energy sector, as firms produce more patents for clean alternative energy increase, they also generate fewer patents enhancing the productivity of fossil fuels, such as energy refining and exploration (Popp and Newell 2012). Similarly, automobile companies react to increases in fuel prices by conducting more innovation in "clean" cars (electric, hybrid and hydrogen) and less innovation in "dirty" (combustion engine) cars (Aghion et al. 2016). The potential impact of changing the direction of innovation is large. Gerlagh (2008) finds that the optimal carbon tax necessary to reduce emissions can be cut in half if one assumes that clean energy R\&D replaces carbon-producing $\mathrm{R} \& \mathrm{D}$, rather than technology-neutral $\mathrm{R} \& \mathrm{D}$. Thus, while it is important to acknowledge the role of properly pricing environmental resources for shaping the direction of innovation, governments could do even more to direct innovation away from dirtier technologies by also removing unnecessary subsidies on fossil fuels (see, e.g. Asmelash 2017). 


\section{POLICY \#2: SUPPORT ENVIRONMENTALLY-FRIENDLY R\&D}

Although the types of demand-side environmental regulations we have just discussed may encourage some early-stage innovations, such regulations tend to favor innovations in technologies that are already relatively close to market (Johnstone et al., 2010; Popp, 2010). This suggests that timing is important. That is, $\mathrm{R} \& \mathrm{D}$ support is necessary early in the innovation process to ensure the development of technologies that can be subsequently pushed closer to the market by demand-side support.

Sensible innovation policy for environmental protection should include subsidies for research (Acemoglu et al., 2012; Acemoglu et al., 2016). In principle, government expenditures to support innovation should be equal to the size of knowledge spillovers (Goulder and Schneider, 1999). Although it is notoriously difficult to measure spillovers and their effects on innovation decisions, several lines of analysis suggest that government spending on R\&D for environment-friendly technologies should be increased significantly relative to current levels (Nemet and Kammen, 2007; Chan and Anadón, 2016; Pless et al., in preparation). 4

There are numerous ways to design and allocate government-funded R\&D support. We describe and discuss evidence on the effectiveness of two common approaches-indirect fiscal incentives for $\mathrm{R} \& \mathrm{D}$, such as tax credits, and direct funding, such as grants for $\mathrm{R} \& \mathrm{D}$. We also consider the role of R\&D conducted by government laboratories and research institutions.

\footnotetext{
4 Popp (2016) shows that there is room to expand renewable energy R\&D budgets, but does not recommend a specific level of funding.
} 


\section{Indirect Fiscal Incentives for R\&D}

Governments can subsidize private sector innovation through indirect fiscal incentives such as R\&D tax credits. Such tax credits - which reduce corporate tax payable - are granted for corporate expenditure on activities that qualify, according to broad government definitions, as "research". Tax incentives have the advantage of not explicitly favoring specific technologies, and being more predictable and reliable for financial planning than funding that must be won through competitions, if implemented over the long-term. ${ }^{5}$ Fiscal incentives can also be used to target other broad objectives, if designed to provide more favorable credits for certain innovative activities (e.g., certain industries, collaborations, types of firms, or technologies). However, because they can make marginal projects profitable, tax credits often encourage firms to invest in innovation related to projects or technologies that are close to market with high short-run returns rather than new technologies that are still far from market (Hall and van Reenen, 2000).

\section{Evidence on Effectiveness: Input Additionality}

Tax credits for R\&D expenditures have become an increasingly popular policy tool, and many studies have examined the effectiveness of such incentives on firms' R\&D expenditures - often referred to as 'input additionality' (i.e., the marginal increase in firm R\&D spending as a result of additional R\&D support). For example, in a study of nine OECD countries over a 19-year period, Bloom et al. (2002) find that a 10\% decrease in the cost of R\&D due to tax credits stimulates a $1 \%$ increase in the level of $R \& D$ in the short-run and a $10 \%$ increase in the long-run. Lokshin and Mohnen (2012) study firms in the Netherlands and find evidence of additionality on average as well. ${ }^{6}$

\footnotetext{
${ }^{5}$ Although tax incentives for R\&D have been relatively stable in some regions, such as in the U.K., they remain subject to repeal and uncertain in others.

${ }^{6}$ For further evidence on input additionality effects, see Duguet (2010) and Hægeland T. and J. (2007), who study firms in France and Norway, respectively.
} 
Evidence on Effectiveness: Output Additionality

Although the most direct objective of these tax incentives is to increase business R\&D expenditures (i.e., input additionality), the ultimate goal is to stimulate innovation, growth, and other productivity outputs - i.e., output additionality. There is growing evidence regarding the positive impact of $\mathrm{R} \& \mathrm{D}$ tax incentives on innovation outcomes. For example, Czarnitzki et al. (2011) study Canadian firms from 1997 to 1999-when one-third of all firms and two-thirds of high-technology firms used R\&D tax credits-and find evidence of innovation output effects. Most recently, Dechezleprêtre et al. (2016b) identify causal evidence of the impacts of R\&D tax incentives on some innovation outputs (quality-adjusted patents) in the UK. Cappelen et al. (2008) and Falk et al. (2009) provide further evidence of the impact of R\&D incentives on innovation outcomes.

\section{Targeting Incentives}

It is important to keep in mind that $\mathrm{R} \& \mathrm{D}$ tax credits are usually available for all or most companies within an economy that are investing in innovation. This means tax credits tend to incentivize $R \& D$ on marginal projects (i.e., those closest to market) rather than entirely new technologies, and they also do not necessarily steer our innovation systems towards environmentally-friendly outcomes. However, policymakers can offer fiscal incentives that do target specific technologies or industries, such as technology-specific investment or production tax credits. For instance, France offers a 30 percent research tax credit for environmental investments up to EUR10o million (and 5 percent for eligible expenses exceeding EUR10o million) (KPMG International, 2014).

\section{Direct Grants or Loans}

Governments can also provide direct financial support for R\&D through grants or loans, and there is growing empirical evidence regarding their impact on firms' innovation outcomes. For example, Jaffe and Le (2015) find that grants increased patenting by firms in the 
manufacturing and service sectors in New Zealand between 2005 and 2009, and that receiving a grant nearly doubles the probability of a firm introducing a new good or service (although effects on process innovations are weaker). Although Jaffe and Le (2015) do not find differential effects for firms of different sizes, firms may indeed respond heterogeneously to grant support. For example, Bronzini and Iachini (2014) find that a grant program in northern Italy did not create additional firm investment in $\mathrm{R} \& \mathrm{D}$ on average, but that there was a substantial increase in investment by small firms. Furthermore, in a recent analysis of the U.S. Department of Energy's Small Business Innovation Research (SBIR) grant program, Howell (2017) showed that grants to small firms can have significant effects on measures of innovative, financial, and commercial success in such firms.

Direct grants and loans can be offered and targeted in various ways, such as through competitions or directed towards specific technologies or types of firms. One advantage of direct support is that resources can be allocated to specific areas where government intervention is particularly needed. However, it is difficult to identify projects that will necessarily produce successful outcomes given the great uncertainty associated with innovation. This suggests that a portfolio approach - i.e., providing support to numerous projects and technologies to reduce overall funding risk - is likely to be most effective. Governments with deep pockets are in an excellent position to support a diversified portfolio of projects. For example, while the U.S. Department of Energy was criticized for its support of the failed Solyndra project, overall the loan guarantee program that supported Solyndra made money, as interest payments from successful projects outweighed losses from failed projects such as Solyndra (Eckhouse and Roston, 2016).

\section{R\&D in Government Laboratories and Research Institutes}

Governments support research not only by providing financial support to private firms and universities, but also through performing research in government laboratories and research institutes (e.g., national laboratories such as the U.S. National Renewable Energy 
Laboratory). Such institutions have proven to be particularly valuable for promoting innovation in clean energy. For example, Popp (2017) finds that clean energy patents assigned to governments are more likely to be cited than clean energy patents from other institutions, signalling patent quality and highlighting the high value of research performed at government institutions. Moreover, government articles on clean energy technology are more likely to be cited by patents than similar articles from any other institution, including universities. This suggests that clean energy research performed at government institutions plays an important role in linking basic and applied research.

The high value of government-performed clean energy research is different than what is found in other sectors, where university research tends to produce the most highly cited output (e.g. Jaffe and Trajtenberg 1996, Trajtenberg, Henderson, and Jaffe 1997). Why might government research be more important for energy than other sectors? Both Mowrey et al. (2010) and Weyant (2011) find that government research helps new energy technologies overcome roadblocks to commercialization. For instance, significant energy innovations typically have disproportionately large capital expenses, leaving a role for collaboration with the public sector to provide support for both initial project development and demonstration projects. Such demonstration projects can promote further learning (Mowrey et al., 2010). For example, advances in wind turbines were aided by U.S. Department of Energy-sponsored innovation on multiple turbine components, which complemented private sector efforts and allowed for feedback between public and private sector researchers (Norberg-Bohm 2000).

\section{POLICY \# 3: JUDICIOUSLY SUPPORT EARLY-STAGE DEPLOYMENT}

While economists tend to focus on public support for R\&D, as discussed in section 2 above, there are at least two situations in which support for early-stage deployment of specific technologies is also warranted. 
First, there are often deployment-related market failures that even correct natural capital prices and R\&D support will not address. These include first-of-a-kind costs incurred by the first mover in a new technology. Followers gain the benefit of the lessons learned by the leader, including technical experience, training of personnel (who can be subsequently hired), financial structures and better educated banks, and improved legal and market arrangements. The result is that without government support to address market failures associated with the diffusion of new technologies, socially valuable deployment might occur too slowly, or not occur at all (Jaffe et al., 2005).

Second, there is a "second best" argument for deployment support. Fisher et al. (2017) show that while technology-specific deployment policies such as renewable energy mandates are less cost effective than technology neutral policies, they also result in less redistribution, making them politically more feasible. If government has been unable to correct natural capital prices, perhaps for political reasons - such that the "demand pull" is weak, or R\&D externalities cannot be internalized and thus the "supply push" is also too weak deployment support for environmentally-friendly innovations might be able to compensate. These types of interventions may be particularly important to avoid crossing a particular planetary boundary where there is little time left for more economically efficient policies to be enacted. In climate change, for instance, there is growing evidence that there is little, if any, time remaining to meet globally-agreed goals (Pfeiffer et al. 2016; McGlade and Ekins, 2015), so more interventionist measures may be needed.

Should deployment support be technology neutral? This question relates to the question of the appropriate direction of innovation. The use of technology neutral policies, a conventional recommendation of economists, focuses attention on the lowest cost alternative to meet policy goals, implicitly favoring cheaper technologies. If all environmental externalities have been internalized, the cheapest technology is more likely to be an environmentally beneficial technology. But as it is very hard or indeed impossible for policy to account for all environmental externalities, policymakers must be aware of the direction of 
innovation they are explicitly selecting with a technology-neutral policy. If this direction threatens planetary boundaries, more technology specific policies should be considered.

How specific should such support be? In general, no more specific than is required. Consider a renewable energy target aimed at reducing local air pollution, contributing to energy security and meeting climate objectives. Several policies could be put in place to meet the target. A "renewable portfolio standard" would leave it to market forces to determine which renewable sources are deployed to meet the target. The renewable energy that is currently cheapest is more likely to be selected, even if this may not be optimal (Way et al., 2017). However, no one technology will be fully able to meet all future clean energy demands. Thus, complementary policies to promote the development of low-emission technologies further from the market are also needed. Direct deployment subsidies can be targeted to drive adoption of specific technologies. For example, the California Solar Initiative has successfully deployed solar, and 53\% fewer solar installations would have occurred in the region without the subsidies (Hughes and Podolefsky, 2015). Similarly, feed-in tariffs, which provide payments for generating renewable power, may target specific energy sources. Feed-in tariffs for solar energy in Germany were more than seven times higher than the feed-in tariffs for wind energy at certain times (OECD-EPAU 2013). As a result, innovation efforts in Germany focused on solar, whereas efforts in countries using renewable portfolio standards have tended to favour wind technology (Johnstone et al., 2010). In short, whether support should be quite so highly specific remains contested: on the one hand, it is often successful for the specific technology chosen, but on the other hand this may not be a cost-optimal use of public funds and can exclude other promising technologies.

\section{POLICY \# 4: SUPPORT COLLABORATIVE R\&D ARRANGEMENTS}

Successful innovation depends on a firm's ability to integrate external information, knowledge, and technologies into its own innovation process (Cassiman and Veugelers, 2002). Some external information and knowledge can be transferred through cooperative 
arrangements that enable collaborations across firms, between the public and private sectors, or between academia and national laboratories and other sectors of the economy. Such collaborations can bring together complementary skills and resources, either between firms or across the innovation spectrum. For instance, universities and national laboratories provide industry with access to cutting edge research, while researchers benefit from accessing industrial and business development expertise. Other benefits include reduced transaction costs, technology risks, and R\&D costs. In this section, we discuss evidence of the effect of collaboration on innovation and how governments can support collaborative R\&D.

\section{Collaboration Impacts on Innovation}

Networks that result from R\&D cooperation can help transfer knowledge and drive innovation (Powell et al., 1996). There is also emerging evidence that collaborative research can produce higher-quality research output, which in turn can translate into innovation. For example, Forti et al. (2013) and Wuchty et al. (2007) show that large networks provide access to new ideas, thus increasing research productivity. Popp (2017) finds that, for alternative energy technologies, both scientific articles and patents with authors from multiple types of institutions (e.g., university and corporations) are cited more frequently, suggesting that collaborations may have positive impacts on research quality.7 Furthermore, in a study of government-sponsored research consortia in Japan, Branstetter (2002) finds consortia research outcomes are positively associated with the level of potential R\&D spillovers within the consortium; results suggest that consortia focusing on basic research are most effective. ${ }^{8}$

\section{Supporting Collaborative R\&D}

\footnotetext{
7 While it could be the case that these collaborations simply expose research to a larger group of people, these results occur even when ignoring self-citations made by the same research organizations, suggesting that is not the case.

8 Other studies showing that cooperation is positively associated with increases in firms' research productivity include Veugelers (1997) and Branstetter and Sakakibara (1998).
} 
Government policies can be used to promote or enhance collaborative R\&D. For example, the National Science Foundation's Industry/University Cooperative Research Program (I/UCRP) supports collaborations between universities and industry to tackle engineering challenges. Public funding can also increase the propensity to engage in R\&D cooperation agreements, so long as sufficient budgetary support is provided (Segarra-Blasco and ArauzoCarod, 2008). Some countries-such as Belgium, Denmark, Italy, Spain, France, and others-do this by providing R\&D tax credits to companies collaborating with a research institute or university (Stepp and Atkinson, 2011).

One example of a successful partnership between numerous actors in the U.S. energy sector is the Innovation Incubator $\left(\mathrm{IN}^{2}\right)$ that supports commercialization of clean energy technologies. IN² was launched by Wells Fargo and Company and the National Renewable Energy Laboratory (NREL), bringing together external industry stakeholders, research institutes, universities, and industry labs. This partnership is unique because it supports early-stage, middle-stage, and later stage companies, providing support for accelerated enterprise growth over time (Adams et al., 2016).

\section{POLICY \# 5: REDUCE BARRIERS TO PRIVATE-SECTOR FINANCING}

One common constraint on innovation is costly external financing, which discourages private sector investment in R\&D (Bond et al., 2005). Private sector financing for environmentally-friendly technologies includes the conventional menu of financing options. Early stage private financing is often equity-based: angel and seed finance - increasingly including crowdfunding methods - are suitable for embryonic ideas, venture capital for early stage technologies, with private equity for the scale up phase. Once technologies reach a degree of maturity, debt-based financial options come into play: corporate finance, project finance, green bonds and other crowd-based financing platforms.

While it is not the role of policy to provide private finance to firms, policy makers can maintain an eagle eye on the health of the financial ecosystem to support access to private 
sector funds for environmentally-friendly innovation. Reducing barriers to these various forms of private finance can be an important contribution of government to facilitate the later stages of the innovation process. Options include creating tax schemes that target these later stages of innovation (such as the venture capital trusts in the UK), providing patient capital (i.e., capital that does not require a very fast payback period) through low interest loans.

Furthermore, direct grants can help alleviate some barriers to finance. Recent work studying small firms in the US has shown that grants to small firms increases a firm's chance of receiving private venture capital investment from $10 \%$ to $19 \%$, and nearly doubles the probability of firm survival and successful exit (Howell, 2017). The policy implication is that reallocating support from larger, later stage grants to more numerous small, early stage grants to younger firms may achieve better outcomes (Howell, 2017) and help smaller firms move new ideas from the initial research stage to technology commercialization. ${ }^{9}$

\section{SUMMARY AND CONCLUSIONS}

This article presented and discussed the evidence concerning five policies that governments could use to support environmentally-beneficial innovation. We would argue that such policies should be considered in any portfolio of innovation policies aimed at protecting global environmental systems, especially given the urgency of addressing additional pressures on sustainability from climate change risks. Based on our review of these policies and some of the evidence regarding their effectiveness, we recommend that innovation policy prioritize the following actions:

\footnotetext{
${ }^{9}$ For another example of the impacts of direct subsidy programs to small business, see Lerner (2000).
} 
1) Price natural capital properly: This includes implementing more stringent environmental regulations and policies that address environmental externalities and interventions that increase the prices of dirty products, processes, and services;

2) Support environmentally-friendly $R \& D$ and innovation and discourage environmentally-harmful innovation: This includes providing $R \& D$ tax credits and grants in order to reduce the cost to private sector firms of investing in $R \& D$ that promotes sustainability. Government laboratories and research institutes can also be supported to complement private sector R\&D, particularly for large capital intensive research projects. Similarly, removing unnecessary subsidies on fossil fuels will discourage innovation that is environmentally harmful;

3) Support early-stage deployment of clean technologies: This is especially important when there are additional market failures (e.g., learning spillovers, first-ofa-kind costs), when the economically optimal interventions under policies 1 . and 2. are not possible or will not meet urgency implied by planetary boundaries;

4) Support collaborative R\&D: This entails targeting financial support for $R \& D$ activities that specifically bring together multiple entities-such as private sector firms, universities, national laboratories, and more-to capitalize on complementary skills and resources; and

5) Reduce barriers to external financing: This includes policies such as corporate tax relief that rewards investments in clean innovation activities and helps high-risk companies raise funds, not just for early stage R\&D but also for companies engaged in the later stages of the innovation.

This list of policy recommendations is not intended to be exhaustive. We considered several other policies and government interventions aimed at promoting innovative activity and outputs, but these did not make it into our top 5 list. These policies include: creating intellectual property and patent laws that protect environmentally-friendly innovators and do not stifle innovation; setting migration and employment policies that make it easier to 
hire and retain talent across borders; and implementing technology performance standards that require operational improvements.

As we have discussed, the policies we have focused on are already implemented-in various combinations and forms - in many countries around the world, although with varying degrees of success. It is therefore important for policymakers to consider evidence-based best practices and policy designs in the context of their policy objectives. For example, when considering policy options for pricing natural capital, a wide array of instruments is available. The theoretical literature evaluating their effectiveness suggests that market-based instruments provide stronger incentives for innovation relative to mandates for specific technologies or performance standards, and that auctioned emissions permits and emissions taxes more effectively encourage innovation than freely allocated permits (Dechezleprêtre et al., 2017; Milliman and Prince, 1989; Fischer, Parry, and Pizer, 2003; Parry, Pizer, and Fischer, 2003), but the empirical evidence is less conclusive in regards to ranking. ${ }^{10}$ Similarly, when providing support for R\&D, policymakers should assess whether tax credits or direct grants are most appropriate for achieving their objectives, and also consider whether their design can target specific types of innovative activity.

Ultimately, the appropriate mix of policies for driving innovation depends on the policy, economic, and social context, and the relative intensity of market failures thereinparticularly those related to knowledge and environmental spillovers. Although there is a growing literature around the effectiveness of the policy tools discussed in this paper, there remains significant opportunity for enhancing the evidence base of innovation policy effectiveness with a focus on mechanisms that can drive environmentally-friendly innovations in favor of environmentally-harmful innovations. This research especially

\footnotetext{
10 For instance, innovation activity actually decreased when permit trading replaced command-and-control regulation under the 1990 U.S. Clean Air Act Amendments, but became more focused on reducing emissions, rather than just lowering compliance costs (Popp, 2003).
} 
should focus on understanding how these policies impact innovation outcomes (i.e., output additionality) and consider how policies interact. 


\section{References}

Acemoglu, D. (2002). Directed Technical Change. The Review of Economic Studies, 69(4), 781-809.

Acemoglu D., Aghion P., Bursztyn L., \& Hemous D. (2012). The environment and directed technical change. The American Economic Review, 102(1): 131-166.

Acemoglu D., Akcigit U., Hanley D., and W. Kerr (2016). "Transition to clean technology", Journal of Political Economy, 124(1): 52-104.

Adams R., Pless J., Arent D., \& Locklin K. (2016). Accelerating Clean Energy Commercialization: A Strategic Partnership Approach. National Renewable Energy Laboratory, NREL/TP-6A6o-65374.

Aghion, P., and P. Howitt. (1998). Endogenous Growth Theory. Cambridge, MA: MIT Press.

Aghion, Philippe, Dechezleprêtre A., Hémous D., Martin R., and Van Reenen J. (2016). "Carbon Taxes, Path Dependency, and Directed Technical Change: Evidence from the Auto Industry," Journal of Political Economy, 124 (1), 1-51.

Allen, M. R., Frame, D. J., Huntingford, C., Jones, C. D., Lowe, J. A., Meinshausen, M., and Meinshausen, N. (2009). "Warming caused by cumulative carbon emissions towards the trillionth tonne" Nature, 458(7242), 1163-1166.

Ambec, S., M. Cohen, S. Elgie, and P. Lanoie. (2013). "The Porter hypothesis at 20: can environmental regulation enhance innovation and competitiveness? Review of Environmental Economics and Policy 7(1): 2-22.

Arrow, K. (1962). Economic welfare and the allocation of resources for invention. In The rate and direction of inventive activity: Economic and social factors (pp. 609-626). Princeton University Press.

Asmelash, HB (2017), Phasing out fossil fuel subsidies in the G2O: Progress, challenges, and ways forward. Geneva: International Centre for Trade and Sustainable Development (ICTSD)

Baranzini, A., van den Bergh J., Carattini, S., Howarth, R., Padilla, E., \& Roca, J. (2017). Carbon pricing in climate policy: seven reasons, complementary instruments, and political economy considerations. WIREs Climate Change, 8(4).

Bloom N., Griffith R., and J. van Reenen (2002). "Do R\&D Tax Credits Work? Evidence from a Panel of Countries 1979-1997," Journal of Public Economics, 85(1), 1-31.

Bond, S., Harhoff, D., \& van Reenen, J. (2005). Investment, R\&D and Financial Constraints in Britain and Germany. Annales d'Economie et de Statistique, 79, 435-462.

Branstetter, L., \& Sakakibara, M. (1998). Japanese research consortia: A microeconometric analysis of industrial policy. Journal of Industrial Economics, 46(2), 207-233.

Branstetter L.G., Sakakibara, M. (2002). When Do Research Consortia Work Well and Why? Evidence from Japanse Panel Data, The American Economic Review, 92(1), pp. 143-159.

Bronzini, R., Iachini, E. (2014). Are incentives for R\&D effective? Evidence from a regression discontinuity approach. American Economic Journal: Economic Policy, 6(4), 100-134.

Brunnermeier, S.B., and M.A. Cohen (2003), Determinants of Environmental Innovation in US Manufacturing Industries, Journal of Environmental Economics and Management 45, 278-293.

Burtraw, D. (2000), Innovation under the Tradable Sulfur Dioxide Emission Permits Program in the U.S. Electricity Sector, Discussion Paper oo-38, Resources for the Future (RFF), Washington, DC. 
Calel, R., \& Dechezleprêtre, A. (2016). Environmental policy and directed technological change: evidence from the European carbon market. Review Econ Stat, 98, 173-191.

Cappelen A., Raknerud A., and Rybalka M. (2008). "The Effects of R\&D Tax Credits on Patenting and Innovations," Discussion Paper no. 565/2008, Statistics Norway: Oslo.

Cassiman, B., \& Veugelers, R. (2002). R\&D Cooperation and Spillovers: Some Empirical Evidence from Belgium. The American Economic Review, 92(4), 1169-1184.

Chan G., Anadón L.D. (2016). Improving Decision Making for Public R\&D Investment in Energy: Utilizing Expert Elicitation in Parametric Models. EPRG Working Paper 1631, Cambridge Working Paper in Economics 1682, Univeristy of Cambridge: Energy Policy Research Group.

Czarnitzki, D., Hanel, P., and Rosa, J. M. (2011). "Evaluating the Impact of R\&D tax Credits on Innovation: A Microeconometric Study on Canadian Firms," Research Policy, 40(2): 217-229.

Dechezleprêtre A., Martin R., \& Mohnen M. (2015). Knowledge spillovers from clean and dirty technologies. Grantham Research Institute on Climate Change and the Environment Working Paper No. 135 .

Dechezleprêtre, A., Martin, R., \& Bassi, S. (2016a). Climate change policy, innovation and growth. Policy Brief, Grantham Research Institute on Climate Change and the Environment and Global Green Growth Institute.

Dechezleprêtre A., Einiö E., Martin R., Nguyen K-T., and Van Reenen J. (2016b). "Do Tax Incentives for Research Increase Firm Innovation? An RD Design for R\&D”, CEP Discussion Paper No 1413.

Dechezleprêtre A. and Popp, D. (2017). "Fiscal and Regulatory Instruments for Clean Technology Development in the European Union," In: Parry, Ian, Pittel, Karen, Vollebergh, Herman (Eds.), Energy Tax and Regulatory Policy in Europe. Reform Priorities. MIT Press, Cambridge, MA, pp. 167213.

Dosi, G. (1988). Sources, procedures and microeconomic effects of innovation, Journal of Economic Literature 26, pp. 1120-1171.

Duguet E. (2010). "The Effect of the R\&D Tax Credit on the Private Funding in R\&D: An Econometric Evaluation on French Firm Level Data," Working Paper.

Eckhouse, Brian and Eric Roston. (2016). “Trump Can’t Kill Solyndra Loan Office That Outperforms Banks," Bloomberg Markets, https://www.bloomberg.com/news/articles/2016-11-28/trump-can-tkill-solyndra-loan-program-that-outperforms-banks.

Falk R., Borrmann J., Grieger N., Neppl-Oswald E., and U. Weixlbaumer (2009). "Tax Incentive Schemes for R\&D," Part 4 of the Evaluation of Government Funding in RTDI from a Systems Perspective in Austria, Vienna: Austrian Institute for Economic Research.

Fischer, C., Parry, I.W.H., Pizer, W.A. (2003). Instrument choice for environmental protection when technological innovation is endogenous. Journal of Environmental Economics and Management, 45(3): 523-45.

Fischer C., Preonas L., and Newell R. (2017). "Environmental and Technology Policy Options in the Electricity Sector: Are We Deploying Too Many?” Journal of the Association of Environmental and Resource Economists.

Forti, E., Franzoni, C., Sobrero, M. (2013). Bridges or isolates? Investigating the social networks of academic inventors, Res. Policy 42, 1378-1388.

Gallagher, K.S. and L.D. Anadon (2017). "DOE Budget Authority for Energy Research, Development, and Demonstration Database," Fletcher School of Law and Diplomacy, Tufts University; Department of Land Economy, University of Cambridge; and Belfer Center for Science and International Affairs, 
Harvard Kennedy School. June 27, 2017.

Gerlagh, R. (2008). A Climate-Change Policy Induced Shift from Innovations in Carbon-Energy Production to Carbon-Energy Savings. Energy Economics 30, 425-448.

Goulder, L. H., \& Parry, I. W. (2008). Instrument choice in environmental policy. Review of environmental economics and policy, 2(2), 152-174.

Greenstone, M. and Looney, A. (2012) "Paying Too Much for Energy? The True Costs of Our Energy Choices”, Daedalus 241(2): 10-30, 2012.

Hægeland T. and J. Møen (2007). "The Relationship Between the Norwegian R\&D Tax Credit Scheme and Other Innovation Policy Instruments," Reports 2007/45, Statistics Norway: Oslo.

Hall, B. and van Reenen, J. (2000). "How Effective are Fiscal Incentives for R\&D? A Review of the Evidence," Research Policy, 29, 449-469.

Hall, B. H., Mairesse, J., \& Mohnen, P. (2010). Measuring the Returns to R\&D. Handbook of the Economics of Innovation, 2, 1033-1082.

Helm D., Hepburn C., \& Mash, R. (2003). "Credible Carbon Policy," Oxford Review of Economic Policy, 19(3), 438-50.

Helm, D. (2011). "Peak oil and energy policy-a critique," Oxford Review of Economic Policy, 27(1), pp. 68-91.

Hepburn, C., Pfeiffer, A., Pretis, F. and Teytelboym, A. (2017) "Peak everything: Are we running out of resources", Oxford Institute of New Economic Thinking, in preparation.

Hicks, J.R. (1932). The Theory of Wages. London: Macmillan.

Howell S. (2017). "Financing Innovation: Evidence from R\&D Grants”, The American Economic Review.

Hughes, J., Podolefsky, M. (2015). Getting Green with Solar Subsidies: Evidence from the California Solar Initiative," Journal of the Association of Environmental and Resource Economists, 2(2), pp. 235-275.

Jaffe A.B. and R.N. Stavins (1995). "Dynamic Incentives of Environmental Regulations: The Effects of Alternative Policy Instruments on Technology Diffusion," Journal of Environmental Economics and Management, 29(3).

Jaffe A.B. and K. Palmer (1997). "Environmental Regulation and Innovation: A Panel Data Study," The Review of Economics and Statistics, 79(4), pp. 610-619.

Jaffe, A.B., Newell, R.G., and Stavins, R.N. (2004). Technology policy for energy and the environment. NBER Innovation Policy and the Economy, Volume 4, eds. Jaffe A.B., Lerner J., and Stern S. MIT Press.

Jaffe, A.B., Trajtenberg, M. (1996). Flows of knowledge from universities and federal labs: Modeling the flow of patent citations over time and across institutional and geographic boundaries, P. Natl. Acad. Sci. 93, 12671-12677

Jaffe, A.B., Le, T. (2015). The impact of R\&D subsidy on innovation: A Study of New Zealand firms. NBER Working Paper No. w21479.

Johnstone, N., I. Haščič and D. Popp (2010). "Renewable Energy Policies and Technological Innovation: Evidence Based on Patent Counts”, Environmental and Resource Economics, 45, pp. 133155 . 
KPMG International (2014). "Taxes and incentives for renewable energy," KPMG International Cooperative, available at: https://assets.kpmg.com/content/dam/kpmg/pdf/2014/og/taxesincentives-renewable-energy-v1.pdf.

Lanjouw, J.O., and A. Mody (1996), Innovation and the International Diffusion of Environmentally Responsive Technology, Research Policy 25, 549-571.

Lanoie, P., Laurent-Lucchetti, J., Johnstone, N., \& Ambec, S. (2011). Environmental Policy, Innovation and Performance: New Insights on the Porter Hypothesis. Journal of Economics \& Management Strategy, 20(3), 803-842.

Lerner, J. (2000). "The government as venture capitalist: the long-run impact of the SBIR program," The Journal of Private Equity 3(2), 55-78.

Lokshin B. and P. Mohnen (2012). "How effective are level-based R\&D tax credits? Evidence from the Netherlands,” Applied Economics, 44(12), 1527-1538.

Malthus, T. (1798). An Essay on the Principle of Population.

McGlade, C., Ekins, P. (2015). The geographical distribution of fossil fuels unused when limiting global warming to $2^{\circ} \mathrm{C}$. Nature, 517 , pp. 187-190.

Milliman, S.R., Prince, R. (1989). Firm incentives to promote technological change in pollution control. Journal of Environmental Economics and Management, 17: 247-265.

Mowrey, D.C., Nelson, R.R., Martin, B.R. (2010). Technology policy and global warming: Why new policy models are needed (or why putting new wine in old bottles won't work). Res. Policy 39, 10111023.

Nedjalkov, A., Meyer, J., Köhring, M., Doering, A., Angelmahr, M., Dahle, S., ... \& Schade, W. (2016). Toxic Gas Emissions from Damaged Lithium Ion Batteries-Analysis and Safety Enhancement Solution. Batteries, 2(1), 5 .

Nelson, R. R. (1959). The simple economics of basic scientific research. Journal of political economy, 67(3), 297-306.

Nemet G., Kammen, D. (2007). U.S. energy research and development: Declining investment, increasing need, and the feasibility of expansion. Energy Policy, 35, 746-755.

Newell, R.G., Jaffe, A.B., \& Stavins, R.N. (1999). The Induced Innovation Hypothesis and EnergySaving Technological Change. The Quarterly Journal of Economics, 114(3), 941-975.

Newell, R.G. (2010). "The role of markets and policies in delivering innovation for climate change mitigation," Oxford Review of Economic Policy, 26(2), pp. 253-269.

Norberg-Bohm, V. 200o. Creating incentives for environmentally enhancing technological change: Lessons from 30 years of U.S. energy technology policy. Technol. Forecast. Soc. 65, 125-148.

OECD-EPAU. 2013. Renewable Energy Policy Dataset, version February 2013. Compiled by the OECD Environment Directorate’s Empirical Policy Analysis Unit (N. Johnstone, I. Haščič, I.M. Cárdenas Rodríguez, T. Duclert) in collaboration with an ad hoc research consortium (A. de la Tour, G. Shrimali, M. Hervé-Mignucci, T. Grau, E. Reiter, W. Dong, I. Azevedo, N. Horner, J. Noailly, R. Smeets, K. Sahdev, S. Witthöft, Y. Yang, T. Dubbeling).

Parry, I.W.H., Pizer, W.A., Fischer, C. (2003). How large are the welfare gains from technological innovation induced by environmental policies? Journal of Regulatory Economics, 23(3): 237-55.

Pless, J., Hepburn C., Rhys, J., \& Farrell, N., in preparation. Inducing and Accelerating Clean Energy Innovation with 'Mission Innovation' and Evidence-Based Innovation Policy Design. 
Pfeiffer A., Millar R., Hepburn C., and Beinhocker, E. (2016). "The ' $2{ }^{\circ} \mathrm{C}$ capital stock' for electricity generation: Committed cumulative carbon emissions from the electricity generation sector and the transition to a green economy," Applied Energy 179: 1395-1408.

Popp D. (2002). “Induced Innovation and Energy Prices,” The American Economic Review 92(1), pp. 160-180.

Popp, D. (2003). Pollution control innovations and the Clean Air Act of 1990. Journal of Policy Analysis and Management, 22(4): 641-60.

Popp, D. (2006), International Innovation and Diffusion of Air Pollution Control Technologies: The Effects of NOX and SO2 Regulation in the US, Japan, and Germany, Journal of Environmental Economics and Management 51(1), 46-71.

Popp, D. (2010), Innovation and Climate Policy, Annual Review of Resource Economics, vol. 2., Gordon C. Rausser, V. Kerry Smith and David Zilberman eds., Annual Reviews, Palo Alto, CA, 275298.

Popp, D., Newell, R.G., \& Jaffe, A.B. (2010). Energy, the Environment, and Technological Change. Handbook of the Economics of Innovation, Elsevier.

Popp, D. and Newell, R. (2012). Where Does Energy R\&D Come From? Examining Crowding Out from Energy R\&D. Energy Economics 34, 980-991.

Popp D. (2016). "Economic analysis of scientific publications and implications for energy research and development," Nature Energy 1.

Popp, D. (2017). "From Science to Technology: The Value of Knowledge From Different Energy Research Institutions," forthcoming at Research Policy.

Powell, W.W., Koput, K.W., Smith-Derr, L. (1996). International Collaboration and the Locus of Innovation: Networks of Learning in Biotechnology, Administrative Science Quarterly, 41(1), pp. 116145 .

Requate T. (2005). Dynamic incentives by environmental policy instruments-a survey. Ecological Economics, 54(2-3), 175-195.

Rockström, J., Steffen, W., Noone, K., Persson, Å., Chapin, F. S., Lambin, E. F., ... \& Nykvist, B. (2009). A safe operating space for humanity. Nature, 461(7263), 472-475.

Segarra-Blasco A., Arauzo-Carod J.M. (2008). Sources of innovation and industry-university interaction: E vidence from Spanish firms. Research Policy, 37, 1283-1295.

Steffen, W., Richardson, K., Rockström, J., Cornell, S. E., Fetzer, I., Bennett, E. M., ... \& Folke, C. (2015). Planetary boundaries: Guiding human development on a changing planet. Science, 347(6223), 1259855 .

Stepp, M., Atkinson, R.D. (2011). “Creating a Collaborative R\&D Tax Credit,” The Information Technology \& Innovation Foundation. Report available at: http://www.itif.org/files/2011-creatingr\&d-credit.pdf.

Tilton, J. (1996). Exhaustible resources and sustainable development, two different paradigms. Resources Policy, 22(1-2), 91-97.

Trajtenberg, M., Henderson, R., Jaffe, A. (1997). University versus corporate patents: A window on the basicness of invention. Econ. Innov. New Technol. 5(1), 19-50.

UN (2017). United Nations. Sustainable Development Goals website. Available at:

http://www.un.org/sustainabledevelopment/. 
Veugelers, R. (1997). Internal R\&D expenditures and external technology sourcing. Research Policy, $26,303-315$.

Way, R., Lafond, F., Farmer, J. D., Lillo, F., and Panchenko, V. (2017). Wright meets Markowitz: How standard portfolio theory changes when assets are technologies following experience curves. (May 9, 2017). Available at SSRN: https://ssrn.com/abstract $=2965695$.

Weyant, J. (2011). Accelerating the development and diffusion of new energy technologies: Beyond the "valley of death." Energy Econ. 33, 674-682.

World Bank (2017). Wealth Accounting, https://data.worldbank.org/data-catalog/wealth-accounting. WHO (2014). World Health Statistics 2014. World Health Organization, Geneva, Switzerland.

Wuchty, S., Jones, B.F., Uzzi, B. (2007). The increasing dominance of teams in production of knowledge. Science 316, 1036-1039. 